\title{
A Kallikrein-like Serine Protease in Prostatic Fluid Cleaves the Predominant Seminal Vesicle Protein
}

\author{
Hans Lilja \\ Department of Clinical Chemistry, University of Lund, Malmö General Hospital, S-214 01 Malmö, Sweden
}

\begin{abstract}
A 33-kD glycoprotein, known as the "prostate-specific antigen," was purified to homogeneity from human seminal plasma. The prostatic protein was identified as a serine protease, and its $\mathrm{NH}_{2}$ terminal sequence strongly suggests that it belongs to the family of glandular kallikreins. The structural protein of human seminal coagulum, the predominant protein in seminal vesicle secretion, was rapidly cleaved by the prostatic enzyme, which suggests that this seminal vesicle protein may serve as the physiological substrate for the protease. The prostatic enzyme hydrolyzed arginine- and lysine-containing substrates with a distinct preference for the former. All synthetic substrates tested were poor substrates for the enzyme. Synthetic Factor $\mathrm{XI}_{\mathrm{a}}$ substrate (pyroglutamyl-prolyl-arginine-p-nitroanilide), and the synthetic kallikrein substrate (H-D-prolyl-phenylalanyl-arginine-p-nitroanilide) were hydrolyzed with maximum specific activities at $23^{\circ} \mathrm{C}$ of 79 and $34 \mathrm{nmol} / \mathrm{min}$ per $\mathrm{mg}$ and $K_{\mathrm{m}}$ values of 1.0 and 0.45 $\mathrm{mM}$, respectively. Synthetic substrates for plasmin, chymotrypsin, and elastase were either not hydrolyzed by the enzyme at all, or only hydrolyzed very slowly.
\end{abstract}

\section{Introduction}

A seminal coagulum forms immediately after the ejaculation of human semen. The predominant protein in seminal vesicle secretion constitutes the structural protein of the clot (1). This protein, known as the high molecular weight seminal vesicle protein (HMW-SV-protein), ${ }^{1}$ forms disulfide-linked high molecular weight complexes but gives major protein bands of some 52,71 , and $76 \mathrm{kD}$ on sodium dodecyl sulfate-polyacrylamide gel electrophoresis (SDS-PAGE) in the presence of reducing agents $(2,3)$. The HMW-SV-protein is cleaved by proteases in the prostatic fluid to several low molecular weight proteins in concurrence with the liquefaction of the clot $(1,3)$. A predominant cleavage product of the HMW-SV-protein is a $5.8-\mathrm{kD}$ basic protein that in its $\mathrm{NH}_{2}$-terminal portion is similar to the histidine-rich region of bovine high molecular weight kininogen (4-6). In the rat, the $\mathrm{NH}_{2}$-terminal portion of this basic protein is also reported to inhibit the secretion of pituitary follicle stimulating hormone (7).

Received for publication 14 March 1985.

1. Abbreviations used in this paper: Con A, concanavalin A; DFP, diisopropylfluorophosphate; DTT, dithiothreitol; HMW-SV-protein, high molecular weight seminal vesicle protein; NPGB, 4-nitrophenyl-guanidobenzoate; $p N A$, 4-nitroanilide; SDS-PAGE, sodium dodecyl sulfatepolyacrylamide gel electrophoresis.

J. Clin. Invest.

(C) The American Society for Clinical Investigation, Inc.

$0021-9738 / 85 / 11 / 1899 / 05 \$ 1.00$

Volume 76, November 1985, 1899-1903
A 30-kD arginyl-cleaving serine protease is predominant in canine prostatic fluid $(8,9)$. Sequence homologies with glandular kallikreins strongly suggest that the canine protease is a member of the kallikrein family (10). A secretory protein from the human prostate, known as "prostate-specific antigen," has recently been shown to be a proteolytic enzyme (11). This 33-kD glycoprotein is present in human prostatic fluid in high concentration (12). Comparison of the reported $\mathrm{NH}_{2}$-terminal sequences of the human prostatic antigen (11) and of the canine protease (10) suggests that these proteins are species analogues. If this assumption is correct, the human prostatic antigen should be a kallikreinlike protease that might cleave a kininogen-related substrate like the HMW-SV-protein. The present investigation presents results that support this hypothesis.

\section{Methods}

Reagents. Unlabeled di-isopropylfluorophosphate (DFP), 4-nitrophenylguanido-benzoate (NPGB)-HCl, and $N^{\alpha}$-benzoyl-L-tyrosine ethyl ester were obtained from Sigma Chemical Co. (St. Louis, Mo); $\left[{ }^{3} \mathrm{H}\right]$ DFP from Amersham Corp. (Amersham, United Kingdom); $\mathrm{EN}^{3}$ HANCE from New England Nuclear (Dreieich, West Germany); pyro-glutamyl-prolylarginine-4-nitroanilide ( $p$ NA) (S 2366), H-D-prolyl-phenylalanyl-argininepNA (S 2302), H-D-valyl-leucyl-arginine-pNA (S 2266), H-D-phenylalanyl-pipecolyl-arginine-pNA (S2238), and H-D-valyl-leucyl-lysine- $p$ NA (S 2251) from Kabi (Stockholm, Sweden); $N^{\alpha}$-benzoyl-arginine-pNA from British Drug Houses (Poole, United Kingdom); and succinyl-(alanine) $3^{-}$ $p$ NA from the Protein Research Foundation (Minoh, Osaka, Japan); carboxymethyl-Sepharose, DEAE-Sepharose, and concanavalin A (Con A)-Sepharose from Pharmacia (Uppsala, Sweden); and Ultrogel Aca 54 from LKB (Bromma, Sweden).

Materials. Human semen and pure prostatic fluid were obtained as previously described (13). Pure seminal vesicle secretion was aspirated from the vesicular ducts during an operation of a male patient for carcinoma in the urinary bladder (3). Coagulated semen was collected in vessels containing $0.5 \mathrm{ml}$ of $0.5 \mathrm{M} O$-phenanthroline that were placed in ice-cold $\mathrm{H}_{2} \mathrm{O}$ directly after ejaculation and then frozen at $-70^{\circ} \mathrm{C}$ until required (1). The coagulated semen was washed free of soluble components and the washed clots were dissolved, reduced, and carboxymethylated as previously described (3). Carboxymethylated clots were extensively dialyzed against $50 \mathrm{mM}$ Tris- $\mathrm{HCl}$ with $0.5 \mathrm{M} \mathrm{NaCl}, \mathrm{pH}$ 8.0.

Electrophoretic techniques. Agarose gel electrophoresis was performed according to standard procedures (14). SDS-PAGE in a 9-17\% polyacrylamide gel gradient was performed according to Blobel and Dobberstein (15). Gels with radioactive proteins were dried after protein fixation and treatment with $\mathrm{EN}^{3} \mathrm{HANCE}$ according to the manufacturer's instructions, and then exposed for $30 \mathrm{~d}$ to $\mathrm{x}$-ray films at $-70^{\circ} \mathrm{C}$ before development. Throughout the purification procedures the individual fractions were analyzed with electroimmunoassay using a polyclonal rabbit antiserum raised against the purified prostatic $33-\mathrm{kD}$ glycoprotein. The electroimmunoassay was run at $60 \mathrm{~V}$ for $16 \mathrm{~h}$ in gels that contained $1 \%$ of antiserum.

Protein purification. The 33-kD prostatic glycoprotein was purified from $50 \mathrm{ml}$ of pooled seminal plasma. The seminal plasma pool was diluted to $150 \mathrm{ml}$ and made up to $10 \mathrm{mM}$ with benzamidine. Concentrations on Diaflo membranes (Amicon Corp., Danvers, MA) (cut off range $=5 \mathrm{kD}$ ) and all chromatographic steps were carried out at $4^{\circ} \mathrm{C}$. 
All buffers used were made up to $10 \mathrm{mM}$ with benzamidine. The seminal plasma pool was applied to a carboxymethyl-Sepharose column (40 $\times 2.5 \mathrm{~cm}$ ) equilibrated with $50 \mathrm{mM}$ Tris- $\mathrm{HCl}, \mathrm{pH}$ 7.5. The prostatic glycoprotein passed through the column with the equilibrating buffer. Fractions containing the protein were pooled and concentrated to $\sim 100$ $\mathrm{ml}$. This pool was applied to a DEAE-Sepharose column $(30 \times 2.5 \mathrm{~cm})$ equilibrated with $30 \mathrm{mM}$ sodium phosphate, $\mathrm{pH} 6.4$. The prostatic glycoprotein passed through the column with the equilibrating buffer and the fractions were pooled and concentrated. The pool was subsequently applied to a Con A-Sepharose column $(16 \times 2.5 \mathrm{~cm})$ equilibrated with $50 \mathrm{mM}$ Tris also containing $0.5 \mathrm{M} \mathrm{NaCl}, \mathrm{pH}$ 7.5. The prostatic glycoprotein was eluted from the column with $0.2 \mathrm{M} \alpha$-methyl-mannoside added to the equilibrating buffer and the fractions were pooled and concentrated (Fig. $1 \mathrm{~A}$ ). The protein pool was applied to an Ultrogel Aca 54 column $(88 \times 1.6 \mathrm{~cm})$ equilibrated with $50 \mathrm{mM}$ Tris and $0.5 \mathrm{M} \mathrm{NaCl}$, pH 8.0 (Fig. $1 B$ ). Fractions reacting with the antibody were pooled and the resulting material found to contain a single band of $\sim 33 \mathrm{kD}$ as judged by SDS-PAGE of reduced samples (Fig. $2 A$ ). The recovery after each purification step is given in Table $I$.

Enzyme assays. Hydrolysis of the tripeptide $p \mathrm{Na}$-substrates and $N^{\alpha}$. benzoyl-arginine-pNA was measured with a UV 260 recording spectrophotometer (Shimadzu Seisakusho Ltd., Kyoto, Japan) at $405 \mathrm{~nm}$. Hydrolysis of $N^{\alpha}$-benzoyl-L-tyrosine ethyl ester was measured at $253 \mathrm{~nm}$. All incubations were performed at $23^{\circ} \pm 2^{\circ} \mathrm{C}$ in $50 \mathrm{mM}$ Tris, $\mathrm{pH} 7.8$. The reaction was initiated by the addition of the purified protein to 1 $\mathrm{ml}$ of substrate solution, while the absorbance was monitored for at least 20 min against a blank containing the substrate solution.

Labeling with $\left[{ }^{3} H\right] D F P$. Samples of purified protein (each containing $\sim 4 \mu \mathrm{g}$ ), pure prostatic fluid $(4 \mu \mathrm{l})$, and seminal plasma $(4 \mu \mathrm{l})$ were incubated with $3 \mu$ l of $\left[{ }^{3} \mathrm{H}\right] \mathrm{DFP}(5 \mathrm{mCi} / \mathrm{ml})$ in $15 \mu \mathrm{l}$ of $50 \mathrm{mM}$ Tris- $\mathrm{HCl}$, pH 7.8, for 10-30 min at room temperature. The samples were subsequently analyzed using SDS-PAGE after reduction and carboxymethylation.

Titration of enzymatic activity. Active site titration with NPGB was performed according to Chase and Shaw (17). The molar concentration of the purified protein was calculated from amino acid analysis assuming a mass of $33 \mathrm{kD}$ and a carbohydrate content of $10 \%$ (12).

Amino acid analysis and sequence determination. The purified protein was reduced for $1 \mathrm{~h}$ with $25 \mathrm{mM}$ dithiothreitol (DTT) in $0.5 \mathrm{M}$ Tris$\mathrm{HCl}$ with $6 \mathrm{M}$ guanidine- $\mathrm{HCl}, \mathrm{pH} \mathrm{8.0,} \mathrm{and} \mathrm{then} \mathrm{carboxymethylated} \mathrm{for}$ $2 \mathrm{~h}$ with $50 \mathrm{mM}$ iodoacetic acid in $0.5 \mathrm{M}$ Tris, $\mathrm{pH}$ 8.0. Carboxymethylated

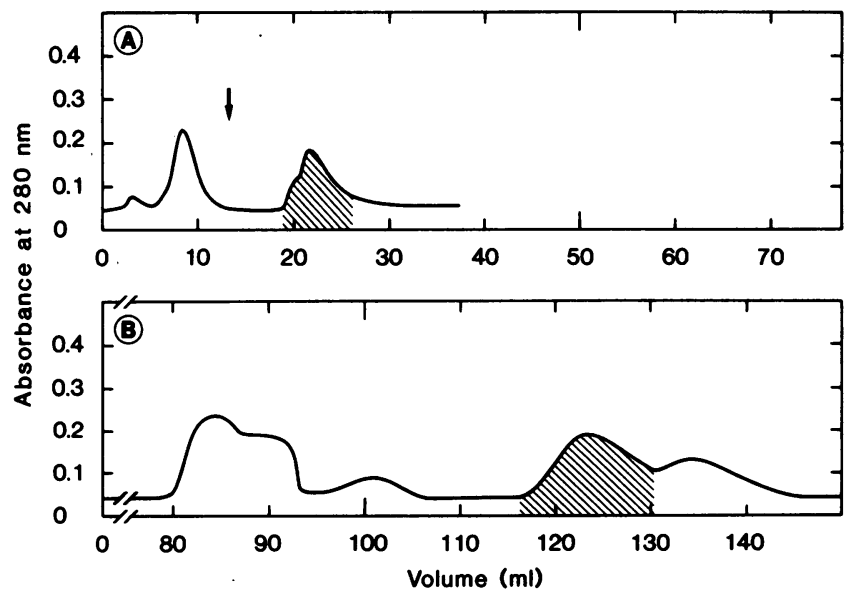

Figure 1. (A) Affinity chromatography on Con A-Sepharose at a flow rate of $25 \mathrm{ml} / \mathrm{h}$ of pooled fractions from DEAE-Sepharose containing the prostatic 33-kD glycoprotein. Elution with $0.2 \mathrm{M} \alpha$-methyl-Dmannoside was started at $\downarrow$. The hatched peak contained the 33-kD glycoprotein. (B) Gel filtration on Ultrogel AcA 54 at a flow rate of 3 $\mathrm{ml} / \mathrm{h}$ of the pooled fractions from $A$. The fractions that were pooled, concentrated, and analyzed by SDS-PAGE in Fig. $2 A$ have been indicated by hatching.

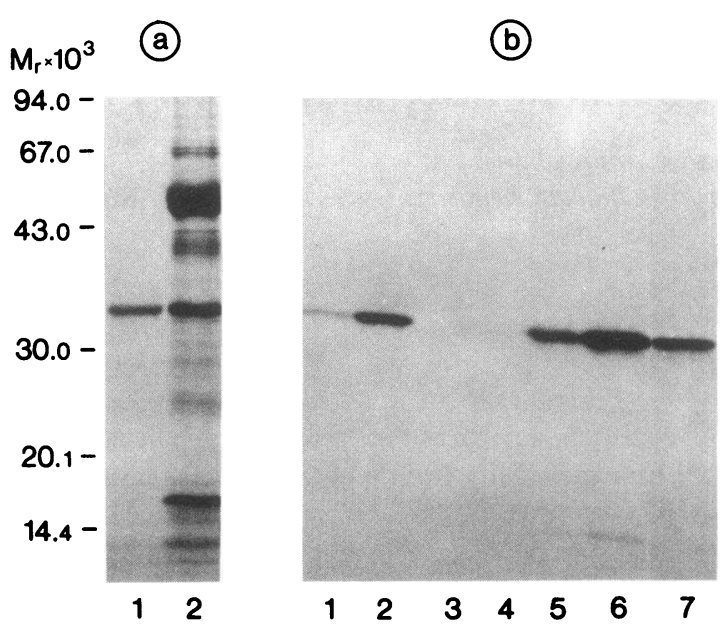

Figure 2. (A) SDS-PAGE in a 9-17\% polyacrylamide gel gradient. All samples were reduced (10 mM DTT) and carboxymethylated before electrophoresis. The proteins were stained with Coomassie Blue R 250 after completed electrophoresis. Lane 1, Purified prostatic protein $(\sim 15 \mu \mathrm{g})$; lane 2, prostatic fluid $(4 \mu \mathrm{l})$. (B) Fluorographic enhancement after SDS-PAGE. Lane 1 , purified protein $(5 \mu \mathrm{g})$ incubated with $\left[{ }^{3} \mathrm{H}\right] \mathrm{DFP}$ for $10 \mathrm{~min}$; lane 2 , purified protein $(5 \mu \mathrm{g})$ incubated with [ ${ }^{3} \mathrm{H}$ ]DFP for $30 \mathrm{~min}$; lane 3 , purified protein $(5 \mu \mathrm{g})$ treated with unlabeled DFP $(10 \mathrm{mM})$ before incubation with $\left[{ }^{3} \mathrm{H}\right] \mathrm{DFP}$ for $30 \mathrm{~min}$; lane 4 , purified protein $(5 \mu \mathrm{g})$ reduced and carboxymethylated before incubation with $\left[{ }^{3} \mathrm{H}\right] \mathrm{DFP}$ for $30 \mathrm{~min}$; lane 5 , prostatic fluid $(4 \mu \mathrm{l})$ incubated with $\left[{ }^{3} \mathrm{H}\right] \mathrm{DFP}$ for $10 \mathrm{~min}$; lane 6 , prostatic fluid $(4 \mu \mathrm{l})$ incubated with $\left[{ }^{3} \mathrm{H}\right] \mathrm{DFP}$ for $30 \mathrm{~min}$; lane 7 , seminal plasma (4 $\left.\mu \mathrm{l}\right)$ incubated with $\left[{ }^{3} \mathrm{H}\right] \mathrm{DFP}$ for $30 \mathrm{~min}$.

protein was hydrolyzed in $6 \mathrm{M} \mathrm{HCl}$ in evacuated sealed tubes at $110^{\circ} \mathrm{C}$ for $24 \mathrm{~h}$. The hydrolysates were analyzed in an amino acid analyzer (model 6300; Beckman Instruments Inc., Fullerton, CA). The $\mathrm{NH}_{2}$-terminal sequence of $\sim 40 \mu \mathrm{g}$ of carboxymethylated protein was analyzed using a 470A gas phase sequencer (Applied Biosystems, Inc., Foster City, CA) with a standard program (18). All phenylthiohydantoin-amino acids were identified with HPLC on a Novapak $C_{18}$ column (Waters Instruments, Inc., Rochester, MN). The column was equilibrated in $29 \mathrm{mM}$ sodium acetate, pH 5.05, with $17 \%$ acetonitrile, and eluted with a linear gradient against $60 \%$ isopropanol.

\section{Results}

Identification of the purified protein. Analysis of the $15 \mathrm{NH}_{2}$ terminal amino acid residues of the purified protein gave the

Table I. Purification of Prostatic 33-kD Glycoprotein

\begin{tabular}{lcclc}
\hline Steps & $\begin{array}{l}\text { Total } \\
\text { volume }\end{array}$ & $\begin{array}{l}\text { Total } \\
\text { protein }\end{array}$ & $\begin{array}{l}\text { Total amount of } \\
\text { 33-kD glycoprotein }\end{array}$ & Recovery \\
\hline & $m l$ & $m g$ & $m g$ & $\%$ \\
Seminal plasma & 50 & 2,300 & 63 & 100 \\
CM-Sepharose & 100 & 600 & 52 & 82 \\
DEAE-Sepharose & 7.0 & 130 & 26 & 41 \\
Con A-Sepharose & 4.0 & 32 & 18 & 28 \\
Ultrogel AcA 54 & 4.2 & 13 & 12 & 19 \\
\hline
\end{tabular}

CM, carboxymethyl.

The amount of prostatic 33-kD glycoprotein was determined by electroimmunoassay. The assay was calibrated by the use of amino acid analysis of the pooled fraction from AcA 54. Total protein was determined according to Lowry (16) with the use of albumin as standard. 
following sequence: Ile-Val-Gly-Gly-Trp-Glu-Cys-Glu-Lys-HisSer-GIn-Pro-Trp-Gln. The yield of the first amino acid $(0.9 \mathrm{nmol}$ of Ile) corresponded to $\sim 75 \%$ of the calculated theoretic yield.

Enzymatic activity of the purified protein. The purified protein did not hydrolyze $N^{\alpha}$-benzoyl-tyrosine ethyl ester or succinyl-(alanine) ${ }_{3} p$ NA. Kinetic data for various synthetic substrates are given in Table II. DFP added to the purified protein in 200fold molar excess abolished its hydrolysis of H-D-prolyl-phenylalanyl-arginine-pNA and pyro-glutamyl-prolyl-arginine- $p \mathrm{NA}$. Active site titration of the purified protein with NPGB demonstrated that $66 \%$ of the protein had enzymatic activity.

Incorporation of $\left[{ }^{3} \mathrm{H}\right] D F P$ in the purified protein. Fluorographic enhancement after SDS-PAGE of the purified protein showed that it incorporated $\left[{ }^{3} \mathrm{H}\right] \mathrm{DFP}$ in a time-dependent manner (Fig. $2 \mathrm{~B}$ ). The incorporation of $\left[{ }^{3} \mathrm{H}\right] \mathrm{DFP}$ was blocked if the purified protein had been treated with unlabeled DFP $(10 \mathrm{mM})$, or if it had been carboxymethylated before it was incubated with the radioactive compound. One single band, with the same mass as the purified protein, incorporated $\left[{ }^{3} \mathrm{H}\right] \mathrm{DFP}$ both in pure prostatic secretion, and in seminal plasma as judged by SDS-PAGE (Fig. 2 B).

Cleavage of $H M W-S V$-protein by the purified protein. Native HMW-SV-protein (in seminal vesicle secretion) and carboxymethylated HMW-SV-protein (from seminal clots) were analyzed by SDS-PAGE (Fig. 3). The intact HMW-SV-protein gave three major bands of 52,71 , and $76 \mathrm{kD}$, as marked with arrows in the figure. The series of minor bands with molecular masses below $50 \mathrm{kD}$ (lanes 1 and 6 in Fig. 3) are intermediate cleavage products of the HMW-SV-protein as previously demonstrated in seminal clots by immunoblotting after SDS-PAGE $(1,3)$. The seminal vesicle secretion and seminal clots were incubated at $37^{\circ} \mathrm{C}$ with the purified $33-\mathrm{kD}$ prostatic protein $(3 \mu \mathrm{g})$. The purified protein rapidly cleaved native or carboxymethylated HMW-SV-protein as shown by the fast disappearance of the 52- and 76-kD bands. The 71-kD band of the intact protein was somewhat more resistant to cleavage (lanes 2-4 and 7 in Fig. 3). Below the weakly stained 71-kD band of HMW-SV-protein in lane 7 a faint $67-\mathrm{kD}$ band of albumin is seen. Proteins with

Table II. Hydrolysis of Synthetic Substrates by the Purified Protein

\begin{tabular}{lllll}
\hline Substrate & $V_{\max }$ & $K_{\mathrm{m}}$ & $K_{\text {cot }}$ & $K_{\text {cad }} / K_{\mathrm{m}}$ \\
\hline $\begin{array}{l}\text { Pyro-glutamyl-prolyl- } \\
\text { arginine- } p \text { NA }\end{array}$ & $n m o l / m i n / m g$ & $m M$ & $s^{-1}$ & $s^{-1} M^{-1}$ \\
$\begin{array}{l}\text { H-D-prolyl-phenylalanyl- } \\
\text { arginine-pNA }\end{array}$ & 79 & 1.0 & 0.064 & 64 \\
$\begin{array}{l}\text { H-D-phenylalanyl-pipecolyl- } \\
\quad \text { arginine- } p \text { NA }\end{array}$ & 36 & 0.45 & 0.028 & 62 \\
$\begin{array}{l}\text { H-D-valyl-leucyl-arginine- } \\
p \text { NA }\end{array}$ & 34 & 0.59 & 0.029 & 49 \\
$\begin{array}{l}\text { H-D-valyl-leucyl-lysine-pNA } \\
N^{\alpha} \text {-benzoyl-arginine- } p \text { NA }\end{array}$ & 2.9 & 4.0 & -0.028 & 7 \\
\hline
\end{tabular}

All assays were performed at $23^{\circ} \pm 2^{\circ} \mathrm{C}$ and $\mathrm{pH} 7.8$ as described in Methods. Michaelis-Menten constants were obtained from Lineweaver-Burk plots of rates of hydrolysis. Hydrolysis of $\mathrm{H}$-D-valyl-leucyllysine- $p$ NA and $N^{\alpha}$-benzoyl-arginine-pNA were measured at a substrate concentration of $1 \mathrm{mM}$.

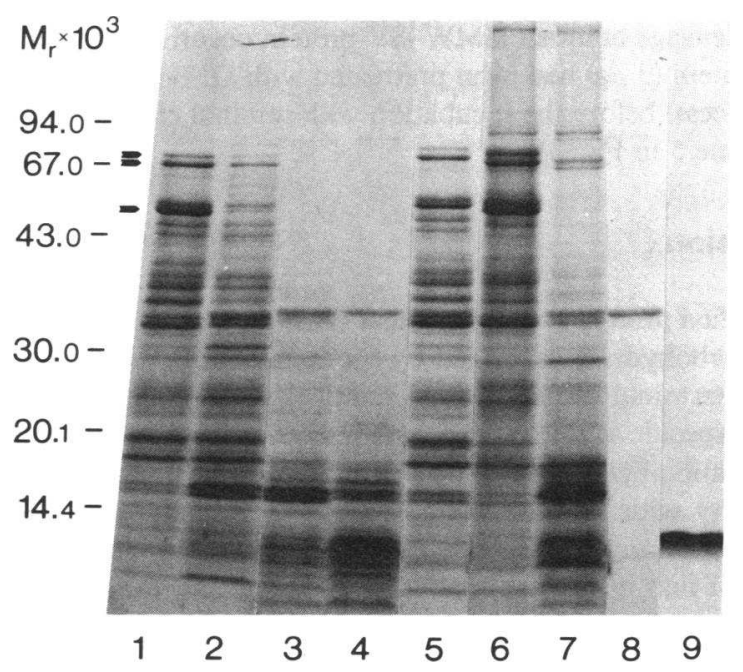

Figure 3. SDS-PAGE in a 9-17\% polyacrylamide gel gradient. All samples were reduced ( $10 \mathrm{mM}$ DTT) and carboxymethylated before electrophoresis. The proteins were stained with Coomassie Blue R 250 after completed electrophoresis. Lane 1, dissolved, reduced, and carboxymethylated seminal clot $(10 \mu l)$; lane 2 , purified prostatic protein $(3 \mu \mathrm{g})$ incubated with the carboxymethylated clot $(10 \mu \mathrm{l})$ at $37^{\circ} \mathrm{C}$, for $2 \mathrm{~min}$; lane 3 , as in 2 but the sample was incubated for $15 \mathrm{~min}$; lane 4 , as in 2 but the sample was incubated for $60 \mathrm{~min}$; lane 5 , purified prostatic protein $(3 \mu \mathrm{g})$ treated with DFP $(10 \mathrm{mM})$ before it was mixed with the carboxymethylated clot $(10 \mu \mathrm{l})$ and incubated at $37^{\circ} \mathrm{C}$ for 30 min; lane 6 , pure seminal vesicle secretion $(2 \mu \mathrm{l})$; lane 7 , purified prostatic protein $(3 \mu \mathrm{g})$ incubated with the seminal vesicle secretion $(2 \mu \mathrm{l})$ at $37^{\circ} \mathrm{C}$, for $5 \mathrm{~min}$; lane 8 , purified prostatic protein $(5 \mu \mathrm{g})$; lane 9 , purified 5.8-kD predominant basic protein.

molecular masses below $20 \mathrm{kD}$ appeared in conjunction with the disappearance of intact HMW-SV-protein. On agarose gel electrophoresis the cleavage of HMW-SV-protein by the purified prostatic protein yielded a series of basic proteins that were indistinguishable from the basic proteins of liquefied semen (Fig. 4). The basic low molecular mass degradation products are HMW-SV-related proteins, as previously shown by immunoblotting $(1,3)$. In addition, acidic cleavage products also appeared when seminal clots (Fig. 4) or seminal vesicle secretion (not shown) were incubated with the purified prostatic protein. The 5.8-kD predominant basic protein in seminal plasma was one of the end products formed after $60 \mathrm{~min}$ (Figs. 3 and 4). However, purified $5.8-\mathrm{kD}$ basic protein was not cleaved further by the purified protein (not shown).

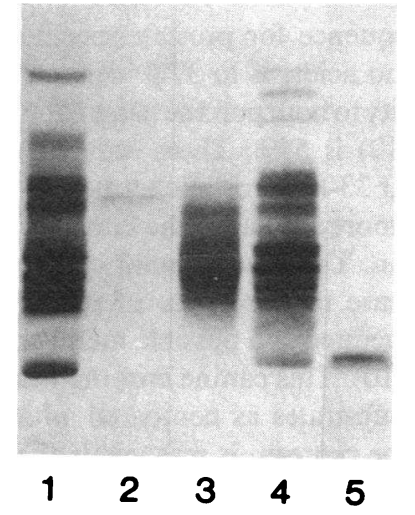

Figure 4. Agarose gel electrophoresis at $\mathrm{pH}$ 8.6. The proteins were fixed and stained with Coomassie Blue R 250 after completed electrophoresis. Anode at top. Lane 1 , liquefied semen $(4 \mu \mathrm{l})$; lane 2 , purified prostatic protein ( $3 \mu \mathrm{g})$; lane 3 , dissolved, reduced, and carboxymethylated seminal clot $(10 \mu \mathrm{l})$; lane 4, purified prostatic protein (3 $\mu \mathrm{g})$ incubated with the carboxymethylated clot $(10 \mu \mathrm{l})$ at $37^{\circ} \mathrm{C}$, for $60 \mathrm{~min}$; lane 5 , purified $5.8-\mathrm{kD}$ predominant basic protein. 
No cleavage of intact HMW-SV-protein occurred if the purified protein $(3 \mu \mathrm{g})$ had been pretreated with DFP (in 200-fold molar excess) before the incubation with seminal clots was initiated (lane 5 in Fig. 3).

\section{Discussion}

The purified protein had a molecular mass of $\sim 33 \mathrm{kD}$ and contained carbohydrate as judged by the high affinity for Con $\mathrm{A}$. Its $\mathrm{NH}_{2}$-terminal sequence was identical to that reported for prostate-specific antigen (11). These results, in conjunction with the prostatic origin of our purified protein, provide evidence of its identity with the prostate-specific antigen. Ban et al. (11) reported that prostate-specific antigen possessed proteolytic activity, but that it was not a serine protease, although the $\mathrm{NH}_{2}$ terminal sequence was very similar to serine proteases, particularly to rat submaxillary tonin (19). Our results clearly demonstrate that the purified protein was a serine protease. DFP destroyed the functional activity of the purified protein. It incorporated $\left[{ }^{3} \mathrm{H}\right] \mathrm{DFP}$ in a specific and time-dependent manner. The result from titration of enzymatic activity excludes the possibility that the demonstrated $\left[{ }^{3} \mathrm{H}\right] \mathrm{DFP}$ incorporation may have been due to a minor contaminant present in the purified material. Furthermore, the sequence (-Val-Leu-Thr-Ala-Ala-His-Cys-) reported for prostate-specific antigen by Ban et al. (11) suggests that His 41 is a member of the catalytic triad of serine proteases (20). The purified protein had no chymotryptic (tyrosine-cleaving) or elastolytic (alanine-cleaving) activity. It possessed a substrate specificity restricted to arginine- and lysine-containing substrates, but with a distinct preference for the former. Synthetic plasma kallikrein-substrate (Pro-Phe-Arg-pNA) and Factor $\mathrm{XI}_{\mathrm{a}}$ substrate (Glu-Pro-Arg-pNA) were the most efficient, but all synthetic substrates tested were poor substrates for the purified protein. However, the prostatic enzyme very rapidly cleaved intact HMW-SV-protein, as judged by the fast disappearance of the 52-, 71-, and 76-kD bands on SDS-PAGE. The presented results do not permit description of one separate band being transformed to another, because of the complexity of the HMWSV-protein cleavage. The enzyme-to-substrate concentration ratio used for the electrophoretic mapping of the HMW-SVprotein cleavage by the purified enzyme was comparable to their physiological ratio in ejaculated semen. The alterations of the protein pattern resulting from cleavage of $\mathrm{HMW}-\mathrm{SV}$-protein by the prostatic enzyme were very similar to the normal proteolysis of HMW-SV-protein in semen (3). It may, therefore, be concluded that the HMW-SV-protein serves as a, or perhaps the, physiological substrate for the purified prostatic protein when prostatic fluid is mixed with the seminal vesicle secretion.

The reported $\mathrm{NH}_{2}$-terminal sequence for prostate-specific antigen (11), consisting of 68 amino acids, is to $37 \%$ identical to porcine trypsin (21), but the identity to both porcine pancreatic kallikrein (22) and to rat tonin (19) is 54\%. These sequence homologies strongly suggest that our $33-\mathrm{kD}$ prostatic serine protease (prostate-specific antigen), is more similar to the family of glandular kallikreins than to trypsin. The predominant canine prostatic enzyme is a serine protease that, because of partial sequence analysis, has also been suggested as a possible member of the glandular kallikrein family (10). This canine enzyme has similar specificities for synthetic substrates as compared with our human protease (8). The canine protease is reasonably the species analogue to our purified protein, as their masses and $\mathrm{NH}_{2}$-terminal sequences are very similar $(10,11)$.

The $\mathrm{NH}_{2}$-terminal portion of the predominant $5.8-\mathrm{kD}$ cleavage product of the HMW-SV-protein has sequence homologies with two portions of the histidine-rich region of bovine high molecular weight kininogen (4). The data presented here indicate that a system consisting of a kallikrein-like enzyme and a kininogen-like substrate is activated at the ejaculation of human semen. It is of pertinent interest to study the sperm interactions of the liberated cleavage products of the HMW-SV-protein.

\section{Acknowledgments}

My thanks are due to Prof. Carl-Bertil Laurell for many invaluable discussions and to Ms. Ingrid Wigheden for expert technical assistance.

This work was supported by grants from the Swedish Medical Research Council (Project No. B83-03X-00581-19C) and from the Faculty of Medicine, University of Lund, Sweden.

\section{References}

1. Lilja, H., and C.-B. Laurell. 1984. Liquefaction of coagulated human semen. Scand. J. Clin. Lab. Invest. 44:447-452.

2. Chaistitvanich, N., and V. Boonsaeng. 1983. Molecular structure of human seminal coagulum: the role of disulfide bonds. Andrologia. 15:446-451.

3. Lilja, H., and C.-B. Laurell. 1985. The predominant protein in human seminal coagulate. Scand. J. Clin. Lab. Invest. 45: In press.

4. Lilja, H., and J.-O. Jeppsson. 1985. Amino acid sequence of the predominant basic protein in human seminal plasma. FEBS (Fed. Eur. Biochem. Soc.) Lett. 182:181-184.

5. Han, Y. N., M. Komiya, S. Iwanaga, and T. Suzuki. 1975. Studies on the primary structure of bovine high-molecular-weight kininogen. Amino acid sequence of a fragment (histidine-rich peptide) released by plasma kallikrein. J. Biochem. (Tokyo). 77:55-68.

6. Han, Y. N., H. Kato, S. Iwanaga, and T. Suzuki. 1976. Primary structure of bovine plasma high-molecular-weight kininogen: the amino acid sequence of a glycopeptide portion (fragment 1) following the Cterminus of the bradykinin moiety. J. Biochem. (Tokyo). 79:1201-1222.

7. Seidah, N. G., K. Ramasharma, M. R. Sairam, and M. Chrétien. 1984. Partial amino acid sequence of a human seminal plasma peptide with inhibin-like activity. FEBS (Fed. Eur. Biochem. Soc.) Lett. 167: 98-102.

8. Isaacs, W. B., and D. S. Coffey. 1984. The predominant protein of canine seminal plasma is an enzyme. J. Biol. Chem. 259:11520-11526.

9. Chapdelaine, P., J. Y. Dubé, G. Frenette, and R. R. Tremblay. 1984. Identification of arginine esterase as the major androgen-dependent protein secreted by dog prostate and preliminary molecular characterization in seminal plasma. J. Androl. 5:206-210.

10. Lazure, C., R. Leduc, N. G. Seidah, M. Chrétien, J. Y. Dubé, P. Chapdelaine, G. Frenette, R. Paquin, and R. R. Tremblay. 1984. The major androgen-dependent protease in dog prostate belongs to the kallikrein family: confirmation by partial amino acid sequencing. FEBS (Fed. Eur. Biochem. Soc.) Lett. 175:1-7.

11. Ban, Y., M. C. Wang, K. W. K. Watt, R. Loor, and T. M. Chu. 1984. The proteolytic activity of human prostate-specific antigen. Biochem. Biophys. Res. Commun. 123:482-488.

12. Wang, M. C., M. Kuriyama, L. D. Papsidero, R. M. Loor, L. A. Valenzuela, G. P. Murphy, and T. M. Chu. 1982. Prostate antigen of human cancer patients. Methods Cancer Res. 19:179-197.

13. Lilja, H., C.-B. Laurell, and J.-O. Jeppsson. 1984. Characterization of the predominant basic protein in human seminal plasma, one cleavage 
product of the major seminal vesicle protein. Scand. J. Clin. Lab. Invest. 44:439-446.

14. Jeppsson, J.-O., C.-B. Laurell, and B. Franzén. 1979. Agarose gel electrophoresis. Clin. Chem. 25:629-638.

15. Blobel, G., and B. Dobberstein. 1975. Transfer of proteins across membranes. J. Cell. Biol. 67:835-851.

16. Lowry, O. H., N. J. Rosebrough, A. L. Farr, and R. J. Randall. 1951. Protein measurement with the Folin phenol reagent. J. Biol. Chem. 193:265-275.

17. Chase, T., and E. Shaw. 1967. p-Nitrophenyl-p-guanido-benzoateHCl: a new active site titrant for trypsin. Biochem. Biophys. Res. Commun. 29:508-514.

18. Hewick, R. M., M. W. Hunkapiller, L. E. Hood, and W. J. Dreyer.
1981. A gas-liquid solid phase peptide and protein sequencer. J. Biol. Chem. 256:7990-7997.

19. Lazure, C., R. Leduc, N. G. Seidah, G. Thibault, J. Genest, and M. Chrétien. 1984. Amino acid sequence of rat submaxillary tonin reveals similarities to serine proteases. Nature (Lond.). 307:555-558.

20. Bloom, D. M. 1971. The structure of chymotrypsin. In The Enzymes. Vol. 3. P. D. Boyer, editor. Academic Press, New York. 187190.

21. Hermodsson, M. A., L. H. Ericsson, H. Neurath, and K. A. Walsh. 1973. Determination of the amino acid sequence of porcine trypsin by sequenator analysis. Biochemistry. 12:3146-3153.

22. Tschesche, H., G. Mair, G. Godec, F. Fiedler, W. Ehret, C. Hirschauer, M. Lemon, H. Fritz, G. Schmidt-Kastner, and C. Kutzbach. 1979. The primary structure of porcine glandular kallikreins. Adv. Exp. Med. Biol. 120A:245-260. 